Abstract

\title{
Enzymatic Fractionation of Protein, Fat and Chitin from Hermetia illucens (L.) (Diptera: Stratiomyidae) ${ }^{\dagger}$
}

\author{
Michael Josias Woods ${ }^{1}$, Louwrens Christiaan Hoffman ${ }^{1,2}$, Elsje Pieterse ${ }^{1}$ and Neill Jurgens Goosen ${ }^{3, *}$ \\ 1 Department of Animal Science, Stellenbosch University, Matieland 7602, South Africa; \\ 16542878@sun.ac.za (M.J.W.); louwrens.hoffman@uq.edu.au (L.C.H.); elsjep@sun.ac.za (E.P.) \\ 2 Centre for Nutrition and Food Sciences, Queensland Alliance for Agriculture and Food Innovation (QAAFI), \\ The University of Queensland, Health and Food Sciences Precinct, 39 Kessels Rd, \\ Coopers Plains, QLD 4108, Australia \\ 3 Department of Process Engineering, Stellenbosch University, Matieland 7602, South Africa \\ * Correspondence: njgoosen@sun.ac.za \\ + Presented at the third International Tropical Agriculture Conference (TROPAG 2019), Brisbane, Australia, \\ 11-13 November 2019.
}

Published: 8 April 2020

\begin{abstract}
Insects have the ability to convert biowaste into valuable functional compounds, such as proteins, fat and chitin. Currently, unlike with conventional commodities, there are few fractionation methods to isolate these compounds for diversification of use. Enzymatic hydrolysis is a possible method to fractionate Hermetia illucens larvae, into protein, fat and chitin. This method is a particularly attractive due to the milder process conditions required compared to chemical methods, the relative ease to control the reaction and minimal formation of unpalatable and toxic by-products. A central composite design was used to help identify the optimum hydrolysis conditions for fractionation. At these conditions the fat recovery was $\sim 81 \%$; substantially more than previous attempts and the fatty acid profile stayed unchanged from the original larvae material. The protein solubility was $\sim 57 \%$, with a degree of hydrolysis of $\sim 22 \%$, and was on par with previous studies. The amino acid profile of the soluble proteins differed from the original larvae material with a slight decrease in the ratio of essential to total amino acids. The insoluble proteins were accounted for with the chitin. A washing-and-sieving step, as means to recover the insoluble proteins from the chitin is envisaged. Also, the spray drying of the protein hydrolysate produced and its functional properties allows for future investigation. This technology allows for higher margins to be made, both environmentally as well as financially, compared to the use of the 'intact' biomass.
\end{abstract}

Keywords: insect protein; enzymatic protein hydrolysis; biomass fractionation; protein solubilization; process optimization

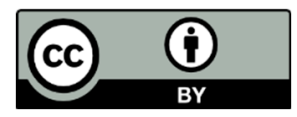

(c) 2020 by the authors. Licensee MDPI, Basel, Switzerland. This article is an open access article distributed under the terms and conditions of the Creative Commons Attribution (CC BY) license (http://creativecommons.org/licenses/by/4.0/). 